\title{
Jejunal motility during cyclic total parenteral nutrition in patients with Crohn's disease
}

\author{
P DUCROTTE, E KONING, F GUILlEMOT, C GUEDON, E LEREBOURS, \\ $P$ DENIS, AND R COLIN \\ From the Groupe de Physiopathologie Digestive et Nutritionnelle, Hôpital Charles Nicolle, Rouen Cedex, \\ France
}

SUMmary Our aim was to study the jejunal motility (a) in seven patients receiving longterm (median: 24 days) cyclic total parenteral nutrition (CTPN) for an acute exacerbation of Crohn's disease involving the ileum and/or the colon without any sign of occlusion and (b) in six healthy volunteers undergoing the same parenteral nutrition for one day after an overnight fast. Continuous recordings, lasting 20 hours, were carried out in patients after correction of their nutritional status and significant improvement of the Crohn's disease activity index. In five of the seven patients, we recorded seven to 14 phase III episodes (PIII) (median: 10), both more frequent and slower during the nocturnal part of the recording time as compared with diurnal. Seven to 18 PIIIs (median: 12) were found in controls. The overall duration of the motor activity was not different between these five patients and controls. In the remaining two patients, no PIII episode was recorded and $\mathbf{7 9} \%$ and $57 \%$ respectively of the whole recording time consisted of irregular motor activity. Our work therefore, shows that: (a) PIIIs remain and have a circadian variation in their periodicity and propagation velocity, in most of our patients undergoing longterm CTPN (b) CTPN does not determine a longer duration of motor rest of the small bowel in patients than in controls submitted for a short period of time to the same parenteral intake.

Total parenteral nutrition (TPN) is an effective therapy in the treatment of a variety of digestive disorders including inflammatory bowel diseases. ${ }^{1-5}$ This efficacy seems related to its nutritional effects and also to the absence of nutrients in the lumen of the gut leading to a 'bowel rest'. Such a 'rest', which remains poorly documented, is probably multifactorial, implying changes in digestive secretions, in antigenic (chemical, dietary, and bacterial) stimulation of the mucosa from the lumen, in mucosal permeability and vascular supply but also in gut motility. In animals, the migrating motor complex (MMC) was not affected by a continuous TPN long enough to induce an atrophy of the small bowel mucosa ${ }^{7}$ and dogs maintained for up to 12 weeks on TPN with nothing but water by mouth still showed MMCs.' In experimental studies, however, only TPN regimens containing glucose and aminoacids without

Address for correspondence: Prof R Colin, Service des Maladies de I'Appareil Digestif, Hôpital Charles Nicolle, 76031 Rouen Cedex, France.

Accepted for publication 27 October 1988. lipids have been tested. ${ }^{8}$ Furthermore, in man, no data concerning intestinal motility during longterm TPN are available.

The purpose of this work, therefore, was to describe the small bowel motor activity in patients with acute Crohn's disease treated by longterm cyclic total parenteral nutrition (CTPN).

\section{Methods}

\section{SUBJECTS}

Seven patients and six healthy volunteers were included in the study after giving informed consent. The seven patients (five men), 19 to 64 years old (mean: 32) were treated by CTPN for an acute exacerbation of Crohn's disease (detailed data in Table 1) unresponsive to usual medical treatment. The disease did not involve the proximal small bowel according to the normality of endoscopy and biopsy specimens taken in the third duodenum. None of the patients had a history of bowel resection, symptoms 
Table 1 Clinical data of the seven patients treated by $C T P N^{*}$ for acute Crohn's disease, in whom manometric small bowel recording was carried out

\begin{tabular}{|c|c|c|c|c|c|}
\hline & Sex & Age & $\begin{array}{l}\text { Location of } \\
\text { the disease }\end{array}$ & Weight & $\begin{array}{l}\text { Duration (days) } \\
\text { of CTPN at entry } \\
\text { in the study }\end{array}$ \\
\hline 1 & $\mathbf{M}$ & 22 & Ileum-colon-anus & 50 & 24 \\
\hline 2 & $\mathrm{~F}$ & 54 & Ileum-anus & 62 & 38 \\
\hline 3 & $\mathbf{M}$ & 33 & Ileum-rectum-anus & 42 & 17 \\
\hline 4 & $\mathrm{~F}$ & 19 & Colon & 41 & 22 \\
\hline 5 & $\mathrm{~F}$ & 44 & Colon & 47 & 12 \\
\hline 6 & $\mathrm{~F}$ & 25 & Ileum-colon-anus & 44 & 30 \\
\hline 7 & $\mathrm{~F}$ & 30 & Colon & 45 & 32 \\
\hline
\end{tabular}

*CTPN: cyclic total parenteral nutrition.

or radiological evidence of mechanical obstruction nor received medication known to have any motor effect. The patient study was carried out between the 12th and the 38th day of CTPN (median: 24). In each, nutritional status had been corrected at the entry in the study.

Patients' results were compared with those of six healthy volunteers (two men), aged 21 to 36 years (mean: 26). None had symptoms or a past history of significant gastrointestinal disease and were not taking medication.

CYCLIC TOTAL PARENTERAL NUTRITION

The same protocol of CTPN was followed in patients and controls with a caloric supply delivered from $5 \mathrm{pm}$ to $8 \mathrm{am}$ the following morning. Fat emulsion (Intralipid (R) Kabivitrum) was first infused separately at a mean flow rate of $0.044 \mathrm{kcal} / \mathrm{kg} / \mathrm{min}$ from $5 \mathrm{pm}$ to $10 \mathrm{pm}$. After which, protein and glucose supply, mixed with electrolytes and vitamins in one bag was infused at a mean flow rate of $0.05 \mathrm{kcal} / \mathrm{kg} /$ min. Parenteral nutrition was given in patients via a central venous catheter and in volunteers through a simple peripheral catheter. The mean caloric to nitrogen ratio was $154 \mathrm{kcal} / \mathrm{g} / \mathrm{N}$.

During the study, controls who had fasted since a standard dinner $(750 \mathrm{kcal})$ taken the evening before the study day and patients were not allowed to take anything by mouth, even fluids.

\section{RECORDING SYSTEM}

Intraluminal pressures were recorded from four sideholes cut in an assembly of four polyvinyl tubes $(0.8 \mathrm{~mm}$ internal diameter). The sensors were located at $5,15,25$, and $35 \mathrm{~cm}$ from a rubber finger stall containing $2 \mathrm{ml}$ mercury and fixed to the tip of the tube to assist positioning. Radio-opaque marks were included in the catheters near the sideholes to facilitate fluoroscopical control of the position of the assembly. Recording lumens were perfused with distilled water $(0.5 \mathrm{ml} / \mathrm{min})$. Pressures from this low compliance hydraulic infusion system were recorded on paper via transducers (Gould Statham, P23ID, Gould Inc, Oxnard, Calif.) by a paper recorder Mingograph Siemens writing at $2.5 \mathrm{~mm} / \mathrm{sec}$.

Individual manometric studies lasted 20 hours. The first morning, patients and fasting volunteers were intubated at $8 \mathrm{am}$. The position of the probe was considered correct when its tip lay below the angle of Treitz. The correct position of the assembly, controlled fluoroscopically was achieved in every subject before $12 \mathrm{am}$. Recording was then continuous from 12 am to 8 am the next morning.

\section{ANALYSIS OF THE TRACINGS}

Three different motor patterns were visually identified by two separate observers.

Phase I (PI) was characterised by a motor rest defined as a period of motor quiescence without any change in basal pressure. Phase II episode (PII) was a period of irregular and random contractions without any propagation; this definition includes PIIs occurring just before a Phase III in a MMC ${ }^{8}$ and PIIs-like episode not followed by a Phase III." Phase III episode (PIII) was identified when all the following criterias were found: (a) bursts of rhythmic contractions, regular in amplitude and frequency (10 to 13 cycles/min); (b) migrating and recorded sequentially at least over the two distal pressure sensors; (c) lasting two minutes or more; (d) followed by a PI. Such a definition includes the PIII of a MMC ${ }^{*}$ and the PIII without any previous PII. ${ }^{8}$

We calculated: (a) the duration of those three different motor activities, expressed (for each of them) as a percentage on the total recording time; (b) the incidence of the PIIIs (number of PIIIs per hour of recording); and (c) for each PIII, its characteristics (frequency, duration, amplitude, and migration velocity) as previously described..$^{10}$ Moreover, we looked for obstructive patterns of motility previously described: ${ }^{11}{ }^{12}$ high pressure $(>20 \mathrm{mmHg})$, prolonged $(>20$ second duration) contractions, minute clustered contractions.

We considered for analysis: (a) the whole tracing; (b) the diurnal and nocturnal parts of the tracings, recording being considered diurnal from 12 am to 10 $\mathrm{pm}$ and nocturnal from $10 \mathrm{pm}$ to $8 \mathrm{am}$ according to Wingate's criterias;" and (c) the three different successive periods determined by CTPN: (i) the period of the day without any caloric supply (12 am$5 \mathrm{pm})$; (ii) the period of lipid infusion (5 pm-10 pm); and (iii) the period of protein and carbohydrate administration (10 pm-8 am).

STATISTICAL ANALYSIS

Wilcoxon's non-parametric test for paired and 

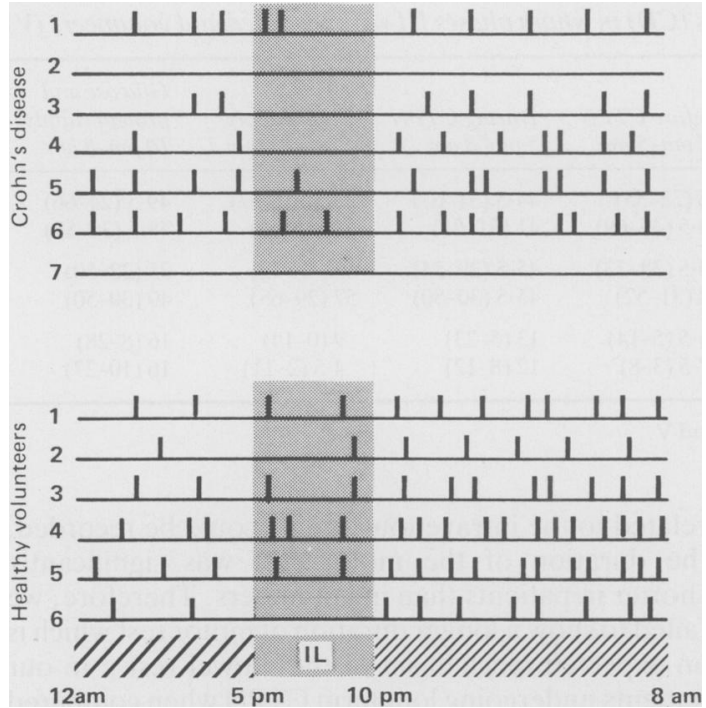

Figure Phases III episodes (each bar represents a Phase III episode) recorded in patients with Crohn's disease and healthy volunteers during CTPN. The shaded area indicates the period of intralipid infusion.

unpaired data and Student's $t$ test were used for the statistical analysis.

\section{Results}

OVERALL RESULTS

During the 20 hours of the manometric study, we recorded PIIIs in five of the seven patients (seven to 14 PIIIs, median: 10) and in all the volunteers (seven to 18, median: 12) (Figure). The characteristics of those PIIIs are detailed in Table 2 . In the remaining two patients (n 2 and n 7) (Figure), no PIII was recorded.

During the whole tracing, the respective durations of PI, PII, and PIII were not different between the five patients in whom PIIIs were recorded and controls (Table 3). In patients nos 2 and 7, the duration of PII lasted $79 \%$ and $57 \%$ of the total recording time respectively, the remaining part of the tracing being a PI activity. In none of the seven patients obstructive patterns of motility were recorded.

\section{RESULTS DURING THE DIURNAL AND}

NOCTURNAL PARTS OF RECORDING

A higher incidence of the PIIIs during the night than during the day was found in patient $(\mathrm{p}<0.01)$ and in control $(p<0 \cdot 01)$ groups. The incidence of the PIIIs was not different between the two groups during the diurnal or the nocturnal part of recording (Table 2). The characteristics of the PIIIs (Table 2), in both groups, such as the migration velocity, decreased during the nocturnal recording. The only circadian difference in the characteristics of the PIIIs between patients and volunteers, was the longer duration of the PIIIs during the night than the day, found in volunteers $(p<0 \cdot 01)$ but not in patients (Table 2$)$.

RESULTS ACCORDING TO INFUSION PROTOCOL During the period without nutritive supply (12 am$5 \mathrm{pm})$ (Table 2) a shorter motor rest $(\mathrm{p}<0.02)$ and a longer duration of the PIIs $(p<0.02)$ was found in patients than in controls, whereas the incidence and the duration of the PIIIs were not different between the two groups.

During parenteral nutrition (5 pm-8 am), the global motor profiles were not different between patients and healthy subjects. During the five hour

Table 2 Characteristics of the phases III recorded in patients $(C D)$ and in healthy volunteers $(V)$

\begin{tabular}{|c|c|c|c|c|c|c|}
\hline & & \multirow[b]{2}{*}{$\begin{array}{l}\text { Diurnal } \\
\text { recording } \\
(12 \text { am-10 pm) }\end{array}$} & \multirow[b]{2}{*}{$\begin{array}{l}\text { Nocturnal } \\
\text { recording } \\
\text { (10 pm-8 am) }\end{array}$} & \multirow[b]{2}{*}{$\begin{array}{l}\text { Period without } \\
\text { supply } \\
\text { (12 am-5 pm) }\end{array}$} & \multicolumn{2}{|c|}{ Cyclic total parenteral nutrition } \\
\hline & & & & & $\begin{array}{l}\text { Lipid } \\
\text { infusion } \\
(5 \mathrm{pm}-10 \mathrm{pm})\end{array}$ & $\begin{array}{l}\text { Glucose and } \\
\text { protein infusion } \\
(10 \mathrm{pm}-8 \mathrm{am})\end{array}$ \\
\hline Incidence $(n / h)$ & $\begin{array}{l}\mathrm{V} \\
\mathrm{CD}\end{array}$ & $\begin{array}{l}0.4(0.2-0 \cdot 6)^{*} \\
0.5(0.2-0.6)^{*}\end{array}$ & $\begin{array}{l}0.8(0.5-1.2) \\
0.7(0.5-0.8)\end{array}$ & $\begin{array}{l}0 \cdot 4(0 \cdot 2-0 \cdot 6) \\
0 \cdot 6(0 \cdot 4-0 \cdot 8)^{*}\end{array}$ & $\begin{array}{l}0 \cdot 4(0 \cdot 6-1 \cdot 2) \\
0 \cdot 2(0-0 \cdot 4)^{*}\end{array}$ & $\begin{array}{l}0 \cdot 8 \\
0 \cdot 7(0 \cdot 5-0 \cdot 8)\end{array}$ \\
\hline Frequency (cycles/min) & $\begin{array}{l}\mathrm{V} \\
\mathrm{CD}\end{array}$ & $\begin{array}{l}11 \cdot 6(11-13) \\
11 \cdot 7(10 \cdot 5-13)\end{array}$ & $\begin{array}{l}11 \cdot 6(11-13) \\
11 \cdot 4(11-13)\end{array}$ & $\begin{array}{l}11 \cdot 4(11-13) \\
11 \cdot 7(10 \cdot 5-12 \cdot 5)\end{array}$ & $\begin{array}{l}11 \cdot 7(11-12 \cdot 5) \\
11 \cdot 4(11-12)\end{array}$ & $\begin{array}{l}11 \cdot 6(11-13) \\
11 \cdot 4(11-13)\end{array}$ \\
\hline Amplitude $\left(\mathrm{cm} \mathrm{H}_{2} \mathrm{O}\right)$ & $\begin{array}{l}\mathrm{V} \\
\mathrm{CD}\end{array}$ & $\begin{array}{l}48(44-49) \\
58(54-63)\end{array}$ & $\begin{array}{l}45(35-60) \\
58(55-60)\end{array}$ & $\begin{array}{l}46(44-47) \\
58(54-60)\end{array}$ & $\begin{array}{l}46(44-49) \\
60(57-63)\end{array}$ & $\begin{array}{l}45(35-60) \\
58(55-60)\end{array}$ \\
\hline Duration (min) & $\begin{array}{l}\mathrm{V} \\
\mathrm{CD}\end{array}$ & $\begin{array}{l}5 \cdot 1(4-6)^{*} \\
5 \cdot 7(5-7)\end{array}$ & $\begin{array}{l}7(5 \cdot 5-7 \cdot 5) \\
6 \cdot 1(5 \cdot 5-7)\end{array}$ & $\begin{array}{l}5 \cdot 3(4-6) \\
5 \cdot 8(5-7)\end{array}$ & $\begin{array}{l}5 \cdot 0(4-5 \cdot 5) \\
5 \cdot 6(4 \cdot 5-6 \cdot 6)\end{array}$ & $\begin{array}{l}7(5 \cdot 5-7 \cdot 5) \\
6 \cdot 1(5 \cdot 5-7)\end{array}$ \\
\hline Velocity $(\mathrm{cm} / \mathrm{min})$ & $\begin{array}{l}\mathrm{V} \\
\mathrm{CD}\end{array}$ & $\begin{array}{l}8 \cdot 2(6-15)^{*} \\
5 \cdot 4(2 \cdot 4-18)^{*}\end{array}$ & $\begin{array}{l}5 \cdot 2(3 \cdot 8-8 \cdot 8) \\
3 \cdot 4(1-14)\end{array}$ & $\begin{array}{l}10 \cdot 6(6-15) \\
7 \cdot 2(2 \cdot 4-18)\end{array}$ & $\begin{array}{l}8 \cdot 0(6 \cdot 0-15) \\
4 \cdot 2(3 \cdot 0-7 \cdot 2)\end{array}$ & $\begin{array}{l}5 \cdot 2(3 \cdot 8-8 \cdot 8) \\
3 \cdot 4(1 \cdot 0-14 \cdot 7)\end{array}$ \\
\hline
\end{tabular}

Values are median and range. ${ }^{*} \mathrm{p}<0 \cdot 01$. 
Table 3 Durations of the different motor patterns in five patients $(C D)$ in whom phases III were recorded and volunteers $(V)$

\begin{tabular}{|c|c|c|c|c|c|c|c|c|}
\hline & & $\begin{array}{l}\text { Whole tracing } \\
12 \text { am-8 am }\end{array}$ & $\begin{array}{l}\text { Diurnal tracing } \\
12 \mathrm{am}-10 \mathrm{pm}\end{array}$ & $\begin{array}{l}\text { Nocturnal tracing } \\
10 \mathrm{pm}-8 \mathrm{am}\end{array}$ & $\begin{array}{l}\text { Before CTPN } \\
12 \mathrm{am}-5 \mathrm{pm}\end{array}$ & $\begin{array}{l}\text { During CTPN } \\
5 \text { pm-8 am }\end{array}$ & $\begin{array}{l}\text { Lipid supply } \\
5 \text { pm-10 pm }\end{array}$ & $\begin{array}{l}\text { Glucose and } \\
\text { protein supply } \\
10 \text { pm-8 am }\end{array}$ \\
\hline Phase I & $\begin{array}{l}\mathrm{CD} \\
\mathrm{V}\end{array}$ & $\begin{array}{l}40(30-61) \\
46(29-62)\end{array}$ & $\begin{array}{l}40(22-56) \\
48 \cdot 0(23-67)\end{array}$ & $\begin{array}{l}49 \cdot 5(24-66) \\
48 \cdot 5(30-58)\end{array}$ & $\begin{array}{l}26(22-55) \\
53 \cdot 5(45-69)\end{array}$ & $\begin{array}{l}44 \cdot 5(31-63) \\
41(31-61)\end{array}$ & $\begin{array}{l}33 \cdot 5(21-57) \\
41(33-68)\end{array}$ & $\begin{array}{l}49 \cdot 5(24-66) \\
48 \cdot 5(30-58)\end{array}$ \\
\hline Phase II & $\begin{array}{l}\mathrm{CD} \\
\mathrm{V}\end{array}$ & $\begin{array}{l}49(34-58) \\
43(30-53)\end{array}$ & $\begin{array}{l}59(40-73) \\
47 \cdot 5(30-67)\end{array}$ & $\begin{array}{l}35(22-50) \\
40(30-50)\end{array}$ & $\begin{array}{l}60 \cdot 5(38-73) \\
38(31-52)\end{array}$ & $\begin{array}{l}45 \cdot 5(29-54) \\
45 \cdot 5(30-50)\end{array}$ & $\begin{array}{l}63(43-73) \\
57(29-65)\end{array}$ & $\begin{array}{l}35(22-50) \\
40(30-50)\end{array}$ \\
\hline Phase III & $\begin{array}{l}\mathrm{CD} \\
\mathrm{V}\end{array}$ & $\begin{array}{l}11(5-19) \\
11(6-18)\end{array}$ & $\begin{array}{l}10(4-12) \\
4 \cdot 5(3-10)\end{array}$ & $\begin{array}{l}16(8-28) \\
16(10-27)\end{array}$ & $\begin{array}{l}6 \cdot 5(5-14) \\
7 \cdot 5(3-8)\end{array}$ & $\begin{array}{l}13(5-23) \\
12(8-12)\end{array}$ & $\begin{array}{l}9(0-14) \\
4 \cdot 5(2-11)\end{array}$ & $\begin{array}{l}16(8-28) \\
16(10-27)\end{array}$ \\
\hline
\end{tabular}

Values are median and range: ${ }^{*} \mathrm{p}<0 \cdot 01$. Comparisons are between $\mathrm{CD}$ and $\mathrm{V}$.

lipid infusion ( $5 \mathrm{pm}-10 \mathrm{pm})$, we showed a lower incidence of the PIIIs than during the period before CTPN $(p<0.01)$ or the period of glucose and protein infusion $(p<0.01)$ only in the patient group (Figure). Despite this lower incidence of the PIIIs, the respective durations of the three motor patterns were not different during this period from those found before and after lipid infusion (Table 3). In the control group, the lipid infusion also led to a lower incidence of the PIIIs but this decrease did not reach statistical signification.

During glucose and protein administration, recordings were not different between the two groups (Table 3).

\section{Discussion}

Our study shows, after a CTPN long enough to improve the physical and nutritional status of the patients, that the motor activity of the upper small bowel not involved histologically by Crohn's disease is in most of the patients, quite similar to the motor profile recorded in healthy volunteers undergoing CTPN for a day after an overnight fast.

The persistence of the typical fasted motor pattern of recurrent PIIIs, except in two patients, confirms previous results in animal studies. ${ }^{7}$ Moreover, we have found in patients and controls, in spite of the lack of luminal content, the circadian variation in the periodicity and the propagation velocity of the PIIIs described in healthy volunteers by Kumar and Wingate ${ }^{13}$ during oral feeding. This result intensifies the hypothesis they have made that circadian variation in MMC propagation velocity, found both in man and animals, ${ }^{13}$ is a true biorhythm and not related to variations of intraluminal content. Lastly, it could be said that this persistence of the PIIIs is a useful phenomenon which prevent bacterial overgrowth. ${ }^{14}$ Our second important finding, is that the duration of the motor rest was not longer in patients than in controls; even more, during the period of the day without CTPN, when no motor effect possibly related to the intravenous supply could be recorded, the duration of the motor rest was significantly shorter in patients than in volunteers. Therefore, we failed to show a longer duration of motor rest which is an expected mechanism of the 'bowel rest', 6 in our patients undergoing longterm CTPN when compared with controls submitted to the same parenteral intake for a short period.

The precise effects of TPN on small bowel motility could have been assessed by the comparison of the motor patterns recorded in patients at the beginning and after a month of CTPN. It is ethically difficult, however, to perform small bowel manometry with the methodology we used in the early stages of an acute exacerbation of Crohn's disease when patients suffer from severe abdominal pain, diarrhoea or symptoms of subocclusion. On the other hand, for obvious ethical reasons, it is impossible to maintain healthy volunteers for up to three or four weeks under TPN. Moreover, the motor findings in the small intestine not involved by Crohn's disease could not be extrapolated to the segments of the gut involved by the disease, even if, despite the normality of biopsy specimens in the upper small intestine at the entry in the study, patchy lesions of Crohn's disease could be present. This fact could explain manometric findings in patients 2 and 7 , in whom no PIII could be recorded and more than half of the recording time consisted of a PII activity. Another explanation for this absence of PIII could be a possible subacute obstruction. ${ }^{12}$ Symptoms of subocclusion were absent, however, and $x$-ray examination was normal in all of our patients at the entry in the study. Moreover, obstructive patterns of motility 1112 were looked for but not found. Lastly, we could not exclude the hypothesis of a bacterial overgrowth to explain the motor activity in patients 2 and $7 .{ }^{14}$ Unfortunately, the lack of repeated motility studies after antibiotherapy and/or breath hydrogen measurements does not provide any data to confirm such an hypothesis.

The protocol of nutritive supply that we followed 
permitted us to analyse the motor effects of the different types of nutrients. Our study has confirmed Weisbrodt's results in dogs, ${ }^{8}$ concerning the lack of induction of a motor activity mimicking a fed motor pattern by the intravenous infusion of a formula containing glucose and proteins only. On the other hand, we have confirmed that in almost all the patients the motor effects of an intravenous lipid infusion, previously found in volunteers, ${ }^{15}$ led to a significant decrease in the number of PIIIs. The same tendency was found in the control group. This result suggests again the existence of an extra luminal phenomenon involved in the motor response to fat. ${ }^{15}$

To conclude, our work fails to show a longer motor rest after almost a month of TPN in patients when compared with volunteers submitted to the same parenteral nutritional intake. Therefore, it provides some arguments against the concept of an increased motor rest induced by TPN and suggests that changes in gut motor activity are not an essential phenomenon in the healing of ulcerated mucosa obtained after CTPN. It suggests that the 'bowel rest' that is referred to when discussing the treatment of Crohn's disease could be related more to secretions and antigen presentation.

The authors are indebted to Dr F Ducrot for helping with the English in the manuscript.

\section{References}

1 Driscoll R Jr, Rosenberg IH. Total parenteral nutrition in inflammatory bowel disease. Med Clin North $\mathrm{Am}$ 1978; 62: 185-201.

2 Dickinson RJ, Ashton MG, Axon AJR, Smith RC, Young CK. Hill GL. Controlled trial of intravenous hyperalimentation and total bowel rest as an adjunct to the routine therapy of acute colitis. Gastroenterology 1980; 79: 1199-204.

3 Lerebours E, Chevallier B, Messing B, Bories Ch, Colin $\mathrm{R}$, Bernier JJ. An evaluation of total parenteral nutri- tion in the management of steroid dependent and steroid resistant patients with Crohn's disease. J Parent Ent Nutr 1986; 10: 274-8.

4 Matuchansky C, Morichau Beauchant M, Druart F, Tapin J. Cyclic (nocturnal) total parenteral nutrition in hospitalized adult patients with severe digestive discases. Gastroenterology 1981; 81: 433-7.

5 Powell Tuck J, Niclsen T, Farwell JA. Team approach to long term intravenous feeding in patients with gastrointestinal disorders. Lancet 1978; ii: 825-8.

6 Matuchansky C. Parenteral nutrition in inflammatory bowel discase. Gut 1986; 27 [suppl]: 81-4.

7 Weisbrodt NW, Copeland EM, Thor PJ, Dudrick SJ. The myoelectric activity of the small intestine of the dog during total parenteral nutrition. Proc Soc Exp Biol Med 1976; 153: 121-4.

8 Weisbrodt NW. Motility of the small intestine. In: Johnson L, ed. Physiology of the gastrointestinal tract. New York: Raven Press, 1987: 631-63.

9 Labo G, Bortolotti M, Vezzadini P, Bonova G, Bersani G. Interdigestive gastroduodenal motility and serum motilin levels in patients with idiopathic delay in gastric emptying. Gastroenterology 1986; 90: 20-6.

10 Kerlin P. Phillips S. Variability of motility of ileum and jejunum in healthy humans. Gastroenterology 1982; 82: 694-700.

11 Camilleri M. Jejunal manometry in the diagnosis of distal subacute mechanical obstruction [Abstract]. Gastroenterology 1988; 94: A57.

12 Summers RW, Anuras S, Green J. Jejunal manometry patterns in health, partial intestinal obstruction and pseudoobstruction. Gastroenterology 1983; 85: 1290300 .

13 Kumar D, Wingate DL, Ruckebush Y. Circadian variation in propagation velocity of the migrating motor complex. Gastroenterology 1986; 91: 926-30.

14 Van Trappen G, Janssens J, Hellemans J, Ghoos Y. The interdigestive motor complex of normal subjects and patients with bacterial overgrowth of the small intestine. J Clin Invest 1977; 59: 1158-66.

15 Guedon C, Ducrotté P, Chayvialle JA, Lerebours E, Denis $P$, Colin R. Effects of intravenous and intraduodenal fat on jejunal motility and on plasma cholecystokinin in man. Dig Dis Sci 1988; 33: 558-64. 